\title{
Water Analysis and Assessment of Periya Sadayampalayam Pond in Erosion Area, Tamil Nadu, India
}

\author{
T. Chitra, T. Ashok Kumar, S. Uthirasamy
}

\begin{abstract}
A study was carried out to access the water analysis of Periyasadayam palayam pond in Erode District, Tamilnadu, India. The study period May to November 2019. Water quality is analysed by physico - chemical parameters. In the present study, the average $B O D$ value was $12.50 \mathrm{mg} / \mathrm{lit}$. The BOD and COD average values 12.50 and $1.94 \mathrm{mg} /$ lit. The BOD of unpolluted water is less than 1.00 $\mathrm{mg} / \mathrm{lit} \mathrm{l}-1 \mathrm{mg} / \mathrm{lit}$, moderately polluted water 2.00 to $9.00 \mathrm{mg}$ l-1while heavily polluted water has BOD of more than $10.00 \mathrm{mg}$ l-1. The BOD has analyzed in different months in pond water fluctuated between 10.04 and $17.10 \mathrm{mg} / \mathrm{lit}$. The pH ranged from (6.7 to 6.8 ), Salinity (162.24 to $165.32 \mathrm{mg} / \mathrm{lit})$. Total Alkalinity (105.34 to $112.64 \mathrm{mg} / \mathrm{lit})$, Calcium (25.13 to 26.84). Nitrate (0.19 to $0.53 \mathrm{mg} / \mathrm{lit})$. Sulphate (19.00 to 31.12) and Phosphate (0.11 to 0.56mg/lit). This study concluded that the seriousness and responsibility of the public to conserve our water resources for healthy living.
\end{abstract}

Keywords: Water quality, Physico-chemical parameters, Periyasadayam palayam pond

\section{Introduction}

Water is essential for the survival of all living organisms. Water is a universal solvent and renewable source. It is important for recycling moisture and regulating climate. Water is naturally the most requirement of all life (Simpi, et al., 2011). Freshwater includes different forms as streams, rivers, ponds and lakes. The diversity of ecosystems can vary since some, like ponds, lakes and rivers, can be isolated from other water sources. The pond is a small body of water around the land, inhabited by different aquatic life forms. Ponds also having to various natural processes taking place in the environment like the hydrological cycle (Adoni and Joshi 1985). The phytoplankton community changes with the change in the environmental condition such as nutrient levels, light intensity, temperature, predators and the type of water sources (Reynolds. and Joworcki 1981). Domestic water runoff and discharge of sewage into the pond are few of the common causes where different nutrients allow the aquatic ecosystems to resulting in their death. Water ecology is best described as the interaction of life with the environment that exists there. A shallow nutrient-rich pond, exposed to sunlight with little water flowing through it will be teaming with the algae and aquatic plants (Singh, et al 2002). It may have very little animal life present because of decreased oxygen levels. In contrast a newly created, deep, spring fed of the pond may have little life of any kind in it because of low temperature and lack of food supply. Chemical concentration is an important source of water contamination trough increase concentration, that introduced during water movement through geological materials (Kataria, and Gupta 2011). According to WHO announced $80 \%$ of water pollution occurs due to domestic waste. Farmers are highly interested in general benefits, like increased agricultural production, low cost water sources, effective way of effluents disposal, source of nutrients, organic matter, etc., but are not well aware of its harmful effect like heavy metals contamination of water quality problems related to human health. The quality of water generally describe to physical, chemical and biological characteristics. Physico-chemical characteristics natures increased by industries effluents and domestic sewage water released in the river, severely polluted and increase the nutrient level of water (Uthirasamy and Chitra, 2020). All the water quality issues facing pond everywhere, eutrophication is a high concern. Eutrophication is usually describing the aging of a pond, resulting due to the accumulation of nutrients, silt, sediments and organic matter in the pond Periya sadayampalayam pond in Erode district, Tamilnadu.

\section{Material and Methods}

In the present study, the selected area located at Periyasadayampalayam in Erode district, Tamilnadu (India). This pond occurs more or less around $103 \mathrm{~m}$ in length, 50 meters in wide and 5 meters in depth. The pond water runoff from south to west direction. The pond received water from three main sources. The main sources of water are harvesting rainwater from Sathyamangalam dam, agricultural water runoff from the nearby areas at Mullamparappu and puthur coming from these ways to the pond. This pond water is mainly used for agriculture purposes only by the local peoples.

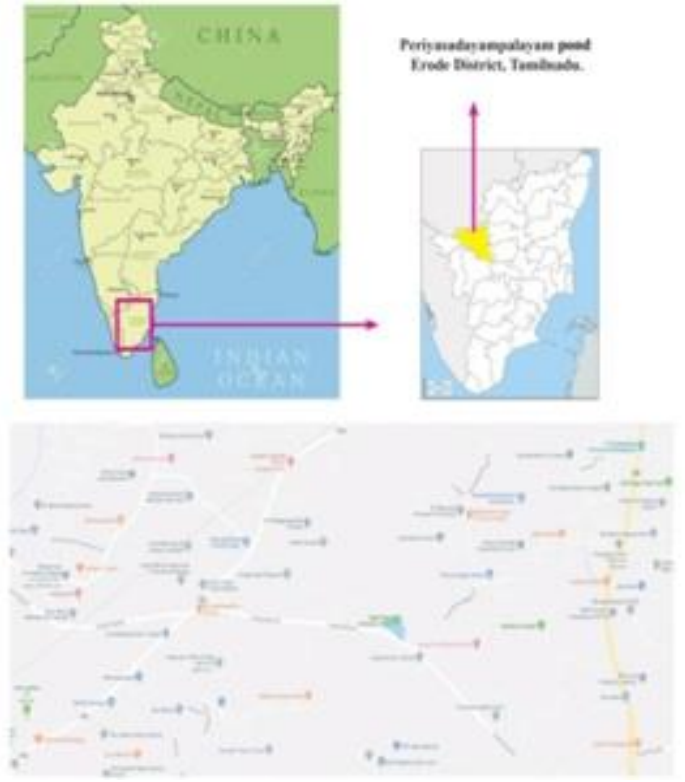

Figure 1: Satellite map of the pond 


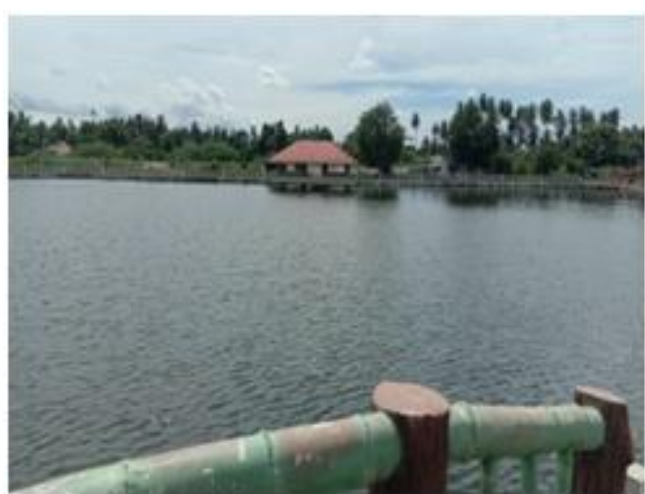

Figure 2: Over view of the study pond

The water sample is collected for physico-chemical analysed and observed plankton diversity was collected monthly. Simultaneously samples collected from all the sampling points from May to November 2019. Composite water samples (subsurface and middle depth) were collected by conical plankton net used for sampling 50- liter pond water was filtered for quantitative analysis. For qualitative analysis the net was towed vertically, horizontally and obliquely.

\section{Physical Parameters}

\section{Colour}

The colour of the canal water was determined visually on the spot.

\section{Temperature}

The temperature of the canal water was measured with the help of a thermometer calibrated from $0^{\circ} \mathrm{C}$ to $100^{\circ} \mathrm{C}$ is used for temperature measurements.

\section{Chemical Parameters}

\section{pH}

The $\mathrm{pH}$ of the samples was determined by using a digital $\mathrm{pH}$ meter. The $\mathrm{pH}$ is the most important factor in determining the corrosive nature of water. The $\mathrm{pH}$ is measured by a portable meter with a glass electrode.

\section{Salinity}

Salinity is an important factor which affects the $\mathrm{pH}$ of water alkalinity and the total hardness of the water. It determines

titration with $0.01 \mathrm{~N}$ Silver nitrate to endpoint with Potassium chromate indicator.

\section{Dissolved Oxygen (DO)}

Dissolved Oxygen is one of the important parameters. Dissolved oxygen measured titrated by wrinkler's method (Titration with $0.25 \mathrm{~N}$ Sodium thiosulphate to starch end point).

\section{Dissolved Carbon Dioxide $\left(\mathrm{CO}_{2}\right)$}

The dissolved carbon dioxide in the water samples were estimated by using the method given by Lind (Lind et al 1974). Carbon dioxide is measured by titrimatically for titration with $0.025 \mathrm{~N}$ Sodium hydroxide to phenolphthalein indicator.

\section{Biochemical Oxygen Demand (BOD)}

BOD was estimated by measuring the amount of oxygen consumed by the microbes present in the sample in five days at $20^{\circ} \mathrm{C}$. The sample was diluted by four times by using the aerated buffered distilled water. The initial oxygen estimations were made in one of the duplicates of each sample and the other were incubated at $20^{\circ} \mathrm{C}$ in dark 5 days and then oxygen estimation separately as a check at regular intervals.

\section{Chemical Oxygen Demand (COD)}

The estimation of chemical oxygen demand was based on the oxidation of the organic content of the sample with potassium dichromate in the presence of silver and sulphuric acid.

Table 1: Average, Standard deviation for pond water quality parameters in Periyasadayampalayam pond

\begin{tabular}{|c|c|c|c|}
\hline S. No & Parameters & Average & Standard deviation \\
\hline 1. & Temperature & 26.24 & \pm 2.939 \\
\hline 2 & $\mathrm{pH}$ & 6.57 & \pm 0.256 \\
\hline 3 & Salinity & 162.2 & \pm 1.294 \\
\hline 4 & Dissolved Oxygen & 4.12 & \pm 0.256 \\
\hline 5 & Dissolved Carbon dioxide & 5.50 & \pm 0.187 \\
\hline 6 & Total Alkalinity & 110.00 & \pm 2.947 \\
\hline 7 & Total Hardness & 90.00 & \pm 0.509 \\
\hline 8 & BOD & 1.80 & \pm 0.104 \\
\hline 9 & COD & 14.00 & \pm 0.1732 \\
\hline 10 & Calcium & 95.40 & \pm 0.244 \\
\hline 11 & Nitrate & 0.14 & \pm 0.256 \\
\hline 12 & Sulphate & 26.00 & \pm 0.623 \\
\hline 13 & Phosphate & 0.19 & \pm 0.446 \\
\hline
\end{tabular}

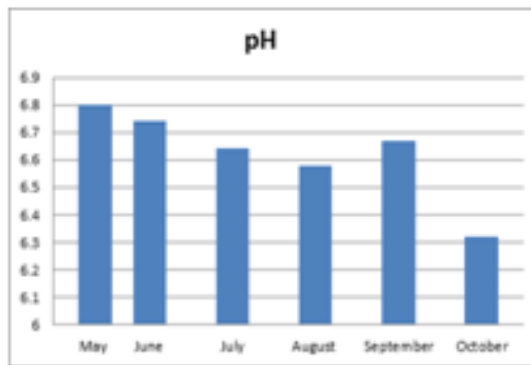

Figure 3: $\mathrm{pH}$

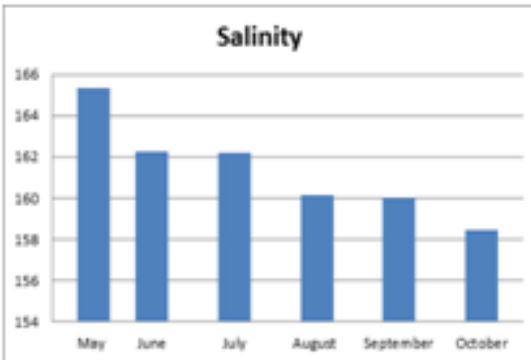

Figure 4: Salinity

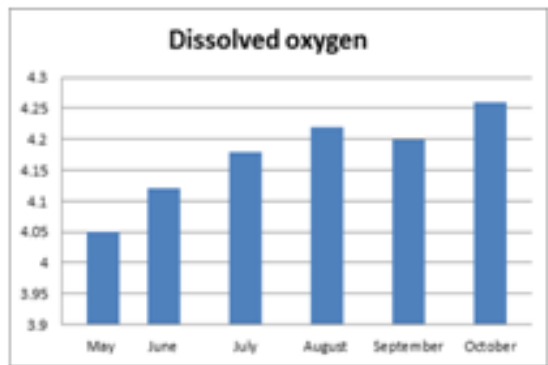

Figure 3: Dissolved oxygen 


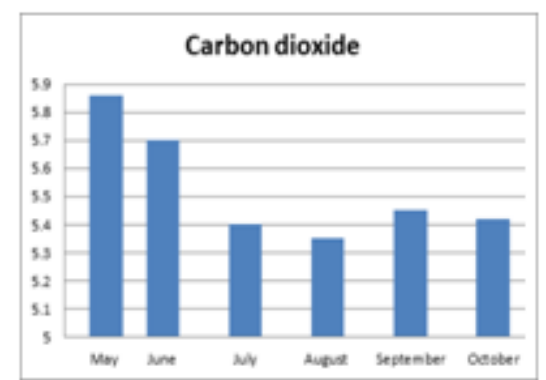

Figure 6: Carbon dioxide

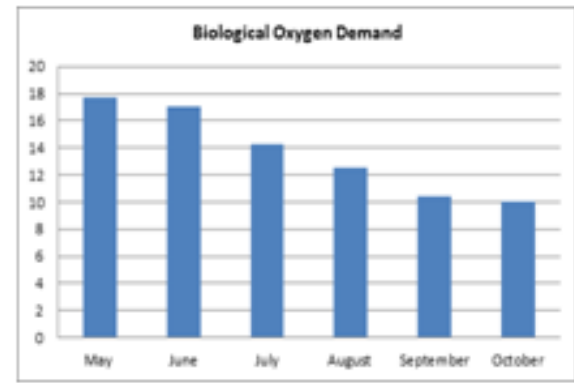

Figure 9: Biological Oxygen Demand

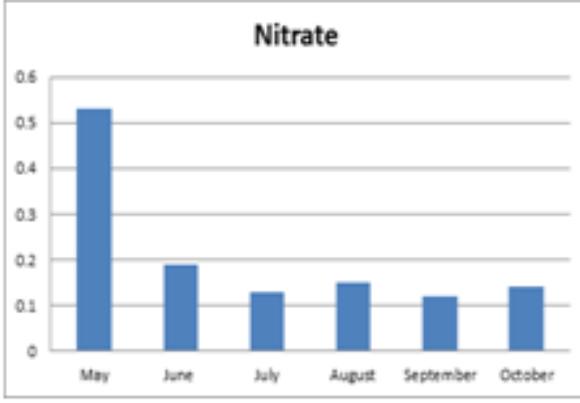

Figure 12: Nitrate

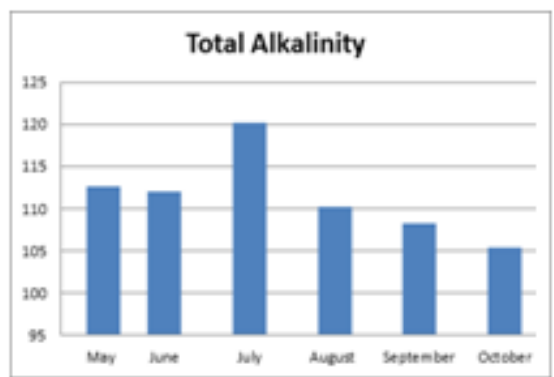

Figure 7: Total Alkalinity

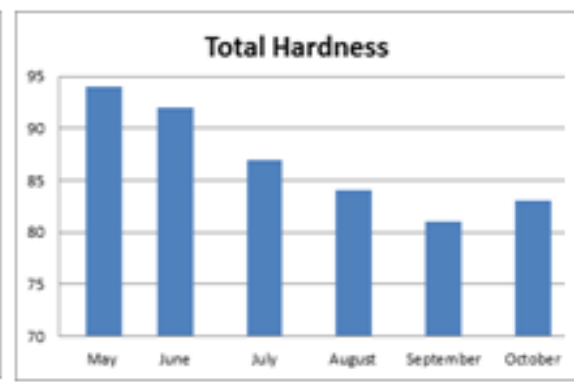

Figure 8: Total Hardness

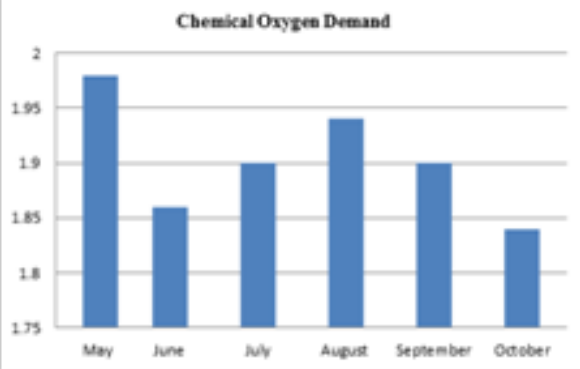

Figure 10: Chemical Oxygen Demand

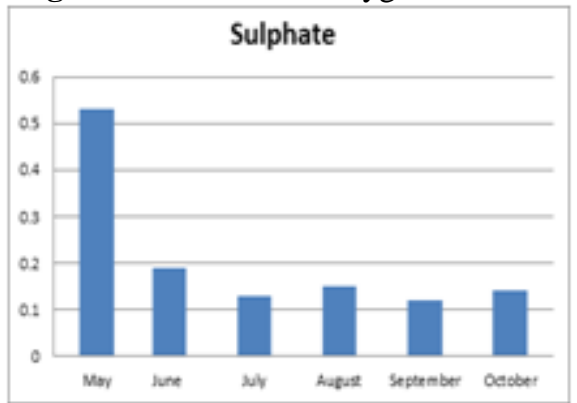

Figure 13: Available Sulphate

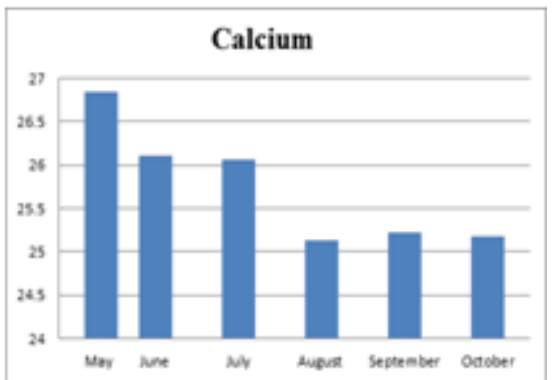

Figure 11: Calcium

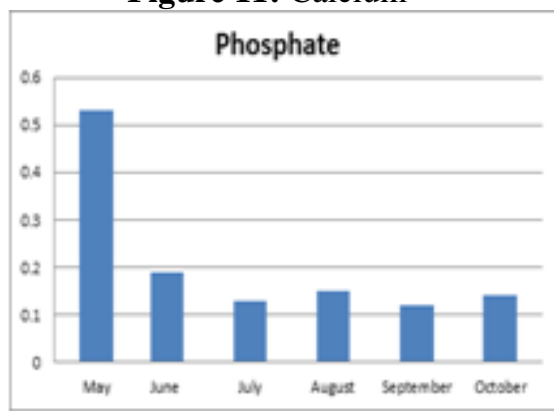

Figure 14: Phosphate

\section{Conclusion}

The present study provides baseline data for the conservation and monitoring of the pond analysis of various physico-chemical parameters that revealed the quality of the pond water. It was found that the pond water was slightly polluted by mixing of organic matters and also by the fertilizers used in the crop field around the pond areas. Planktons present in the water body reflect the average ecological conditions and may be used as indicators of the water quality. In order to know the impact of pollution due to agricultural pesticides, fertilizers and domestic wastewater it was also thought of interest to investigate the physico- chemical parameters of this pond along with the investigation of planktons. These parameters can identify the certain condition for the ecology of living organisms and suggest appropriate conservation and management strategies.

The present study indicated that Periyasadayam palayam pond was quite polluted and water is unsafe for drinking, but may be used for agricultural and domestic purposes. In the future, care should be taken to avoid pollution and give awareness to the public for conservation of pond and also prevent the chemicals from the run of water. This study to be motivated the proper management and assessment of the pond periodically.

\section{Results and Discussion}

The present study is analysed the Physico-chemical characteristics and plankton diversity of Periyasadampalayam in Erode district. The $\mathrm{pH}$ is essential for the normal survival of all organisms and affects the enzymatic activity and affects that distribution of plants. Thus indirectly affect the elemental mobilisation. The $\mathrm{pH}$ values ranged from 6.3 to 6.7. The maximum value of 6.7 was observed in June (Table-1, Fig -3). Dissolved oxygen is the most factor in water quality assessment. DO is essential for successful production since oxygen $\left(\mathrm{O}_{2}\right)$ has a direct influence on feed intake, metabolism and disease resistance. In the present study maximum level of Dissolved oxygen of $4.26 \mathrm{mg} / \mathrm{lit}$ was found in the month of October because during rainy season might be an inflow of surrounding rainwater in a pond. The dynamic oxygen cycle of ponds fluctuates throughout the day due to phytoplankton photosynthesis and respiration. Biological Oxygen Demand (BOD) and Chemical Oxygen Demand (COD): Biological Oxygen Demand gives an idea of the quantity of bio degradable organic present in, which is subjected to aerobic decomposition by microorganisms. Chemical Oxygen Demand is the measure of the oxygen equivalent of the organic matter contained in the water. These are the reliable parameters for judging the extent of pollution in water (Mishra and Saxena 1996) and Uthirasamy and Chitra, 2020). In the present study the average BOD value was $12.50 \mathrm{mg} / \mathrm{lit}$ found in the month of August in the pond. The 
BOD and COD average values 12.50 and 1.94 were found in the month of August in pond water (Table-1, Fig-9 and 10). The BOD of unpolluted water is less than $1.00 \mathrm{mg} / \mathrm{lit} 1-1$ $\mathrm{mg} / \mathrm{lit}$, moderately polluted water 2.00 to $9.00 \mathrm{mg} 1-1$ while heavily polluted water has BOD of more than $10.00 \mathrm{mg} \mathrm{l-1}$ (Adakole, 2007). The BOD has analyzed in different months in pond water fluctuated between 10.04 and $17.10 \mathrm{mg} / \mathrm{lit}$ these indicating the pond status as moderately polluted. From this study, the observed revealed the necessity of conserving this type of pond from any type of pollution and to take serious conserving measures in the future which will give us a safe environment for the human society.

\section{References}

[1] Adakole, J.A. (2007). Bacteriological quality of an urban stream in Northern - Nigeria. Journal of Aquatic Sciences, 22(1): pp1 - 10 .

[2] Adoni, A., Joshi, D.G., Ghosh, K., Chourasi, S.K., Vaishya, A.K., Yadav, M., and Verma H.G.(1985). A work book on limnology.(Pratibha publisher), Sagar.

[3] Kataria, H. C., Gupta, M. K., Kushwaha, S., Kashyap, S., Trivedi, S., Bhadoriya, R. and Bandewar, N. K., (2011). Study of physico-chemical parameters of drinking water of Bhopal city with reference to health impacts. Current World Environment, 6(1): 95-99.

[4] Lind, O.T. (1974). Hand book of common methods in limnology the C.v. Mosby C. p154.

[5] Mishra, S.R., and Saxena, D.N. (1996). Pollution ecology with reference to physcio-chemical characteristics of Morar (Kalpi) river Gwalior (M.P). In: Current Trends in Limnology(Ed. N.KShastree).1:159-184.

[6] Reynolds, C. S. and Joworcki.,(1981). Phytoplankton assemblages and their periodicity in stratifying lake systems. Holarctic Ecology,3(1):41-159.

[7] Singh, S.P.D., (2002). Pathak and R.Singh: Hydro biological studies of two ponds of Satna (MP)India. Eco Environ. Cons, 8, Pp 289-292.

[8] Simpi, B., Hiremath, S.M., Murthy, K.N.S., Chandrashekarappa, K.N. and Patel, A.N.et al.,(2011). Analysis of Water Quality Using Physico-Chemical Parameters Hosahalli Tank Shimoga District, Karnataka, India. Global Journal of Science Frontier Research 11:pp 31-34.

[9] Uthirasamy, S and Chitra, T., (2020). Analysis of physico-chemical characteristics of Cauvery River Pallipalayam, Erode city, Tamilnadu, India, Global Journal for Research Analysis 9(1), pp1-3.

[10] Uthirasamy, S and Chitra, T., (2020). Zooplankton diversity of canal water in Rangampalayam, Erode district, Tamilnadu, India, Journal of Applied Science and Computations 7(5), pp 92-97.

\section{Author Profile}

Dr. T. Chitra did M. Phil, Department of Zoology. She is Associate Professor, Department of Zoology, Erode Arts and Science College, Erode, Tamilnadu, India. (Correspondence Author)

T. Ashok Kumar M.Phil in Zoology Department of Zoology, Erode Arts and Science College, Erode, Tamilnadu, India.
S. Uthirasamy Ph.D in Zoology Department of Zoology, Erode Arts and Science College, Erode, Tamilnadu, India. 